\title{
Epoxy Sheet Plastination on a Rabbit Head - New Faster Protocol with Biodur ${ }^{\circledR}$ E12/E1
}

\author{
Plastinación de Cortes con Resina Epoxi en una Cabeza de Conejo- \\ Nuevo Protocolo Rápido con Biodur® E12/E1
}

\begin{abstract}
Nicolás Ernesto Ottone ${ }^{1,3,4}$; Claudia Andrea Vargas ${ }^{2,3}$; Carlos Veuthey ${ }^{1}$; Mariano del Sol ${ }^{2,4}$ \& Ramón Fuentes Ren $^{1,2}$
\end{abstract}
OTTONE, N. E.; VARGAS, C. A.; VEUTHEY, C.; DEL SOL, M. \& FUENTES, F. Epoxy sheet plastination on a rabbit headnew faster protocol with biodur® E12/E1. Int. J. Morphol., 36(2):441-446, 2018.

SUMMARY: Plastination is an anatomical technique of cadaveric preservation that allows the preservation of anatomical pieces indefinitely, in dry and odorless form. It was created in 1978 by Gunther von Hagens, in Heidelberg, Germany. In particular, the sheet plastination technique, with epoxy resin, allows the generation of thin sections of various anatomical regions, allowing an accurate visualization of anatomical structures of difficult access through dissection or cadaveric exploration. The aim of this work was to present a new sheet plastination protocol with Biodur ${ }^{\circledR}$ E12/E1, which is faster in its implementation, applied, for the first time, in a rabbit head.

KEY WORDS: Sheet plastination; Biodur ${ }^{\circledR}$ E12/E1; Epoxy resin; Rabbit; Head.

\section{INTRODUCTION}

The plastination technique was created in 1978, in Heidelberg, Germany by Profesor Gunther von Hagens (von Hagens, 1979, 1986; von Hagens et al., 1987; Ottone, 2013). This technique allows humans and animals specimens conservation, previously dissected, in a dry, non toxic way and with great durability in time (Ottone et al., 2014). The fundamental steps for this technique are: dehydration, forced impregnation and curing. Sections of specimens can be conserved using epoxy resin or polyester, providing different levels of visualization (micro and macroscopy), with a possibility of teaching and researching (Ottone et al., 2015).

In relation to epoxy sheet plastination, can be thin slices ( 2 to $3 \mathrm{~mm}$ ) or ultrathin $(<2 \mathrm{~mm})$, and can be used for any corporal region with the great advantage that it produces minimal tissue shrinkage compare to polyester sheet plastination (Bickley \& Townsend, 1984; Sora et al., 2002; Sora \& Matusz, 2010;Ottone et al., 2017). This epoxy resin advantage allows analize morphometric parameters of different structures and anatomical regions, applicable to morphological research (Eckel et al., 1993; Sora et al., 2004).
The aim of this work is to show a new thin sheet plastination protocol with epoxy resin (Biodur E12/E1) that gives as a result $2 \mathrm{~mm}$ plastinated sheets in 17 days. This technique was applied in two rabbit heads specimens, that it has not been described yet in literature.

\section{MATERIAL AND METHOD}

We took as reference the E12 sheet plastination protocols implemented by Gunther von Hagens (1986) and Constantin Sora (Sora et al., 2002; Sora \& Cook, 2007; Elnady \& Sora, 2009). However we achieved to make modifications to these protocols, especially during forced impregnation and curing, developing a faster E12 sheet plastination technique, taking just 17 days for $2 \mathrm{~mm}$ slices (Table I). The specimens used were two fresh rabbits heads, males, obtained from the Animal Facility of the Doctoral Program in Morphological Sciences, Faculty of Medicine, Universidad de La Frontera, Temuco, Chile.

\footnotetext{
${ }^{1}$ Laboratory of Plastination \& Anatomical Techniques, Faculty of Odontology, Universidad de la Frontera, Temuco, Chile.

${ }^{2}$ Department of Physical Education, School of Education, Universidad de La Frontera, Temuco, Chile.

${ }^{3}$ Doctoral Program in Morphological Sciences, Faculty of Medicine, Universidad de La Frontera, Temuco, Chile.

${ }^{4}$ Center of Excellence in Morphological and Surgical Studies (CEMyQ), Faculty of Medicine, Universidad de La Frontera, Temuco, Chile.

Funded by Universidad de La Frontera - DIUFRO N DI16-0009
} 
Table I. E12 Fast-Protocol (Present study).

Day 0: Freeze specimen $\left(-25^{\circ} \mathrm{C}: 3\right.$ days $/-80^{\circ} \mathrm{C}: 1$ day).

Day 5: Cut specimen.

Day 5: Dehydration, 1st acetone bath at $-25^{\circ} \mathrm{C}(100 \%)$. Check acetone volume each day.

Day 9: Dehydration, 2nd acetone bath at $-25^{\circ} \mathrm{C}(100 \%)$. Check acetone volume each day.

Day 12: Degreasing with acetone $(100 \%)$ at room temperature.

Day 17: Forced Impregnation: $760 \mathrm{mmHg}$ to $30 \mathrm{mmHg}$ for 45 minutes.

Day 17: Curing with "sandwich" method, in an oven at $50{ }^{\circ} \mathrm{C}$ for 20 hours.

The results corresponds to the development of the new protocol of sheet plastination and the obtained of the coronal slices plastinated of the rabbit head.

A. Sectioning block preparation. To easily section the sample, it is placed in to a wood or cardboard container, and fully filled in with polyurethane foam, till the specimen is completely covered, leaving the block at room temperature for $24 \mathrm{~h}$ till it is completly dry and hard. After, place the container with hard with polyurethane foam in to a $-25^{\circ} \mathrm{C}$ freezer for 3 days, then place it in to a $-80{ }^{\circ} \mathrm{C}$ ultra-freezer for $24 \mathrm{~h}$ to obtein the adequate hardness to cut the sections.

B. Preparation of the block for sectioning. To cut the sample more easily it is placed in a container (wood or cardboard) and covered with polyurethane foam, which hardens in $24 \mathrm{~h}$. The whole block, consisting of the container with the polyurethane-surrounded sample, is placed in a freezer at $-25^{\circ} \mathrm{C}$ for 3 days. Then, the block is placed in an ultra-freezer at $-80^{\circ} \mathrm{C}$ for one day, to obtain the final adequate hardness to do the sections.

C. Sample sectioning. Disengaged the polyurethane block from the container and placed it over the cutting table of the cutting machine that has a measure cutting guide that allows control the slice thickness and a shark band saw blade with 3 teeth per inch. To obtain the $2 \mathrm{~mm}$ coronal sections of the rabbit head, with $1 \mathrm{~mm}$ material waste, we applied liquid nitrogen over the cutting guide to maintain freezed block. After each cut, the slice were placed into a $-20^{\circ} \mathrm{C}$ acetone container and brush cleaned before dehydration.

D. Dehydration \& Degrease. Sections passed througth two consecutive $100 \%$ acetone baths at $-25^{\circ} \mathrm{C}$. Acetone volume was checked every day throughout the dehydration process, which took seven days totally: first bath, 4 days, and the second one, 3 days (Table I). Once the volume of acetone, in the second bath, was superior to $99 \%$ in two consecutive days, the process of dehydration was complete. The next step was degreasing, to eliminate the fat from the slices. We putted the sections in a bath of $100 \%$ volume of acetone at room temperature for five days.
E. Forced impregnation. Once the degreasing was finish, the sections were placed in a mixture of Biodur ${ }^{\circledR}$ E12 (epoxy resin) and Biodur ${ }^{\circledR}$ E1 (hardener) (96:26 p.b.w.), at room temperature $\left(20^{\circ} \mathrm{C}\right)$. The same day the vacuum pump is activated. In this stage the acetone will be extracted as the resin mixture is incorporated into the sections, evidenced by bubbles rising to the surface. During $45 \mathrm{~min}$ the pressure was taken from $760 \mathrm{mmHg}$ to $30 \mathrm{mmHg}$. Once the pressure of $30 \mathrm{mmHg}$ is reached and no more bubbles were observed, forced impregnation was complete.

F. Curing. Immediately the forced impregnation process was complete, the samples were taken out of the resin and the curing chamber were set up, using the "sandwich" method, in which the samples were cured by polymerization in an oven.

The following materials were required for the curing chambers: $3 \mathrm{~mm}$ thick rectangular glass plates (the size of the plates will depend on the size of the samples to be cured) and acetate sheets (same size as the glass plates).

Acetate sheet was placed over a glass plate, then a Biodur $^{\circledR}$ E12/E1 (96:26 p.b.w.) mixture was pour onto the acetate. Tissue sections were placed over the mixture an were covered on top, with the same Biodur ${ }^{\circledR}$ E12/ E1mixture. A second acetate sheet was placed on the slices, and with a wooden stick the mixture was distributed over the sections, being sure to eliminate bubbles of the sections surface. Then, the second glass plate is placed on. The glass plates were pressed together to ensure even distribution and complete cover of the resin mixture between the sections. Then the glass plates were fixed placing binder clips around the sides.

The "sandwich" chamber was placed inside an oven at $55{ }^{\circ} \mathrm{C}$ for $20 \mathrm{~h}$. At the end, the chamber can be dismantled, removing the clips and glass plates to leave the sections between the sheets of acetate. These can then be peeled off to leave the hard, dry sections embedded in resin. If necessary the excess resin can be removed by cutting round the sections with scissors. 


\section{RESULTS}

The innovative in this new sheet plastination protocol are the speed and easiness to take place the forced impregnation in just $45 \mathrm{~min}$ and curing process during only $20 \mathrm{~h}$. With this new protocol we obtained 2 $\mathrm{mm}$ thick coronal sections of rabbit head, with high
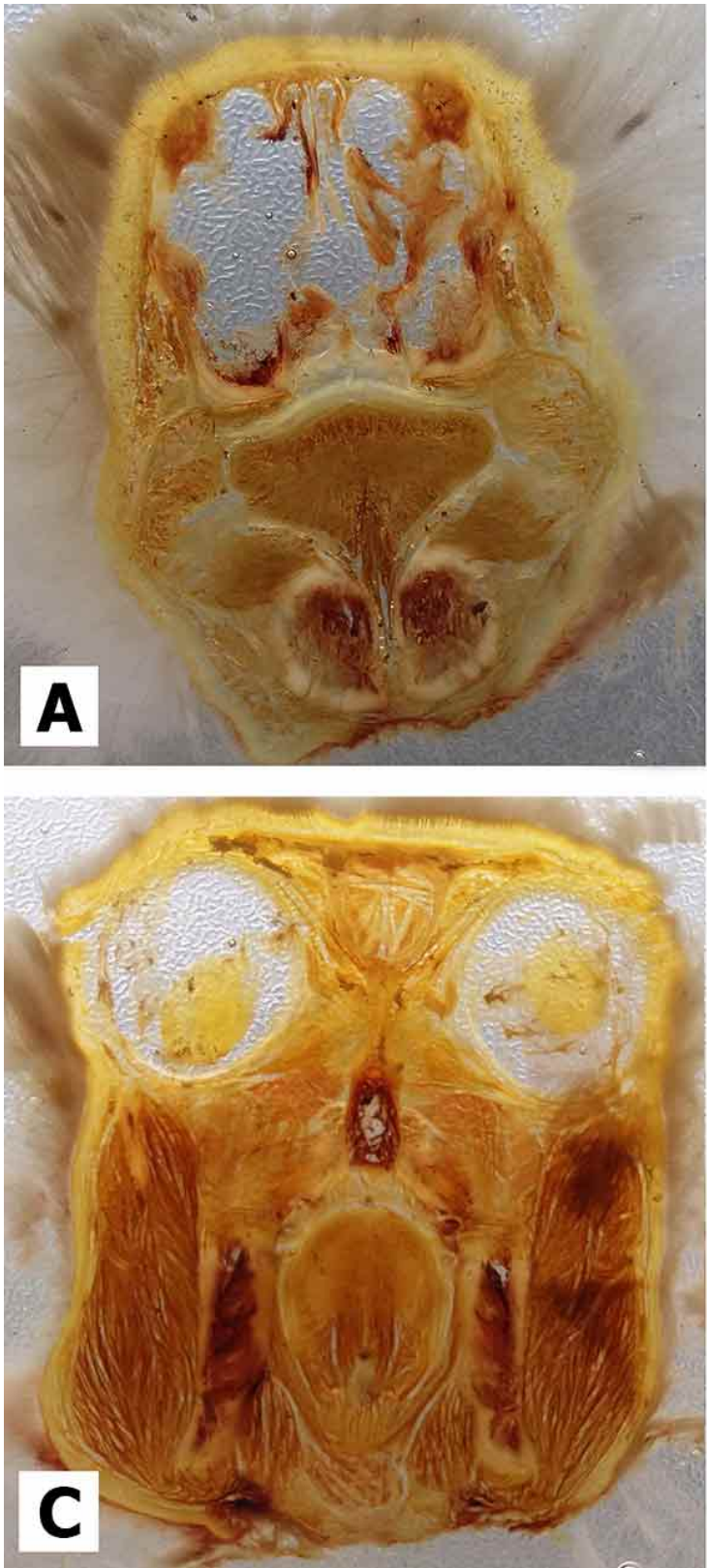

anatomical quality and definition, and strong colour contrast among several morphological structures (Fig. $1 \mathrm{~A}, \mathrm{~B}, \mathrm{C})$. There were no shrinckage of tissues, including the brain (Figs. 1D), conserving the sections the original tissue shape (Fig. 1).
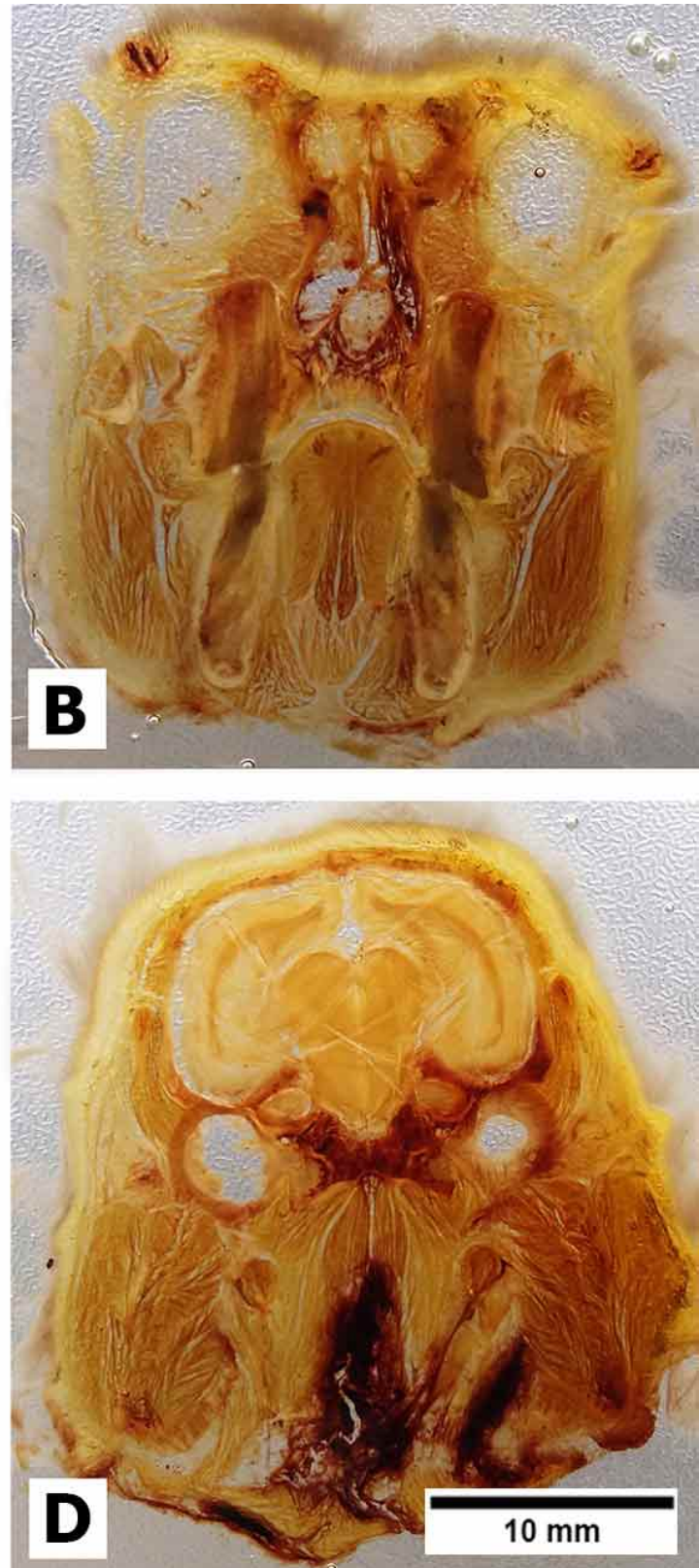

Fig. 1. Coronal plastinated sections of rabbit head, $2 \mathrm{~mm}$ thick. A. Coronal section at the level of the nostrils. B. Coronal section at the level of the anterior part of the orbital cavity, in which the teeth and mandible, as well as the masticatory musculature, are appreciated. C. Coronal section at the middle of the orbital cavity. D. Coronal section at the posterior portion of the orbital cavity, with visualization of the central nervous system. In all the slices, and especially the last one that allows to identify brain and brainstem, these structures conserve the shape and allow to evidence the almost absent retraction of the tissues. 


\section{DISCUSSION}

Block and cutting. In relation to sectioning block preparation, most authors indicated direct specimen cutting without using any substance to easily manipulate the specimen (von Hagens, 1986; Eckel et al.; Sora et al., 2002; Scali et al., 2015a,b), other authors used gelly to inmerse the specimen (Nash et al., 2005a,b; Liang et al., 2014) and polyurethane foam (Ottone et al., 2016; Present study). The selected temperature for most authors for cooling the block and do the cutting was $-80{ }^{\circ} \mathrm{C}$ (Eckel et al.; Cook, 1997; Cook \& Al-Ali, 1997; Sora et al., 2002; Sora et al., 2008), opposite to the present study that placed the block in a -25 ${ }^{\circ} \mathrm{C}$ freezer for 3 days and after one day in a $-80{ }^{\circ} \mathrm{C}$ ultrafreezer. Other studies cooled the block at $-75^{\circ} \mathrm{C}$ (Sora \& Cook), $-85^{\circ} \mathrm{C}$ (Scali et al., 2015a,b) (Table II).

Dehydration. Most authors made dehydration with acetone at $-25{ }^{\circ} \mathrm{C}$ (von Hagens, 1986; Cook \& Al-Ali; Nash et al., 2005a,b; Sora \& Cook; Elnady \& Sora; Scali et al., 2015a,b; Ottone et al., 2017; Present study). Nevertheless the biggest difference among the authors is time, going from 20 to 22 weeks (Scali et al., 2015a,b), 5 weeks (Cook \& Al-Ali), to 7 days (Elnady \& Sora; Present study) (Table II).

Degreasing. This is a very important step in sheet plastination, because it contributes to fat elimitation to provide a greater slices transparentation. In this way, the most powerfull chemical (but with greater toxicity), is $\mathrm{MeCl}$, applied to the slices for one day (Elnady \& Sora). Some authors combined acetone and $\mathrm{MeCl}$ (Cook; Cook \& AlAli), while other authors just used acetone with time variations (Table II).

Forced impregnation. Some authors made forced impregnation at low temperature $\left(0-5^{\circ} \mathrm{C}\right)(\mathrm{Cook} \& \mathrm{Al}$-Ali; Zhang \& Lee, 2002; Leaper et al., 2005; Nash et al., 2005a,b; Elnady \& Sora; Liang et al.; Thorpe Lowis et al., 2016). Scali et al. (2015a,b) applied forced impregnation at -8 a 0 ${ }^{\circ} \mathrm{C}$, while Sora \& Cook and the present study did the process at room temperature.

There are different modalities of mixture and products types used, mainly Biodur, as it can seen in Table II. Two authors did not indicate the epoxy resin brand (Cook; Scali et al., 2015a,b). There are no variations indicated in the different manners to combine the distinct epoxy resine types, with its correspondent catalyst, acelerator, etc.

Something interesting to remark in this step, crucial for the correct conservation and posterior slices visualization, is the application time of forced impregnation. In this study, we did the forced impregnation in just 45 minutes, to maximum vaccum, checking the ending of impregnation process. This is the minimum time described in relation to other authors (between 24 to 48 hours of forced impregnation) (Table II).

Curing. Most authors applied "sandwich" type curing methodology, and just three authors used "flat chamber" (Table II). In every case, the same combination of resines as used to forced impregnation were used. The advantage of "sandwich" method, is the rapidity and easiness for slices assemble and diassemble, in addition to the possibility to do greater slices amount for curing. In the case of "flat chamber" a limitation can exist, regarding to crystals size and the difficulty to assamble. Time also varies, in our study, just 20 hours curing, less time comparing to others authors (Table II).

According to the total time development for this epoxy resin plastination technique, we have had established a 17 days long protocol. Elnady \& Sora proposed a 22 days protocol, Cook 36 days, Zhang \& Lee, Leaper et al. and Liang et al. a 72 days technique and the longest one, Scali et al. (2015a,b) 159 days, amongh other authors (Table II).

\section{CONCLUSIONS}

The plastination technique, created by Gunther von Hagens in Heidelberg, Germany in 1978, is still a novel technique in both application and development.

Plastinated slices were transparent, dry, resistant, odor free, of unlimited durability and easy to maintain (Sora et al., 2004; Fritsch et al., 2006; Sora \& Cook; Elnady \& Sora; Soal et al., 2010; Ottone et al., 2016; Ottone et al., 2017).

The sections also present anatomical proportions with minimal shrinkage and does not require decalcification (Sora et al., 2007; Adds \& Al-Rekabi, 2014; Thorpe Lowis et al; Ottone et al., 2017.). According to Sora et al. (2002), this property makes it easy to take morphological measurements for research.

The specimens are of great value, not only for undergraduate teaching but also for advanced training programs in sectional topography and for training specialists in computed tomography and magnetic resonance imaging (Sora \& Cook; Sora et al., 2012). Finally, it is an aid to surgical planning because it allows excellent viewing of human and animal anatomy. 
OTTONE, N. E.; VARGAS, C. A.; VEUTHEY, C.; DEL SOL, M. \& FUENTES, F. Epoxy sheet plastination on a rabbit head- new faster protocol with biodur@ E12/E1. Int. J. Morphol., 36(2):441-446, 2018.

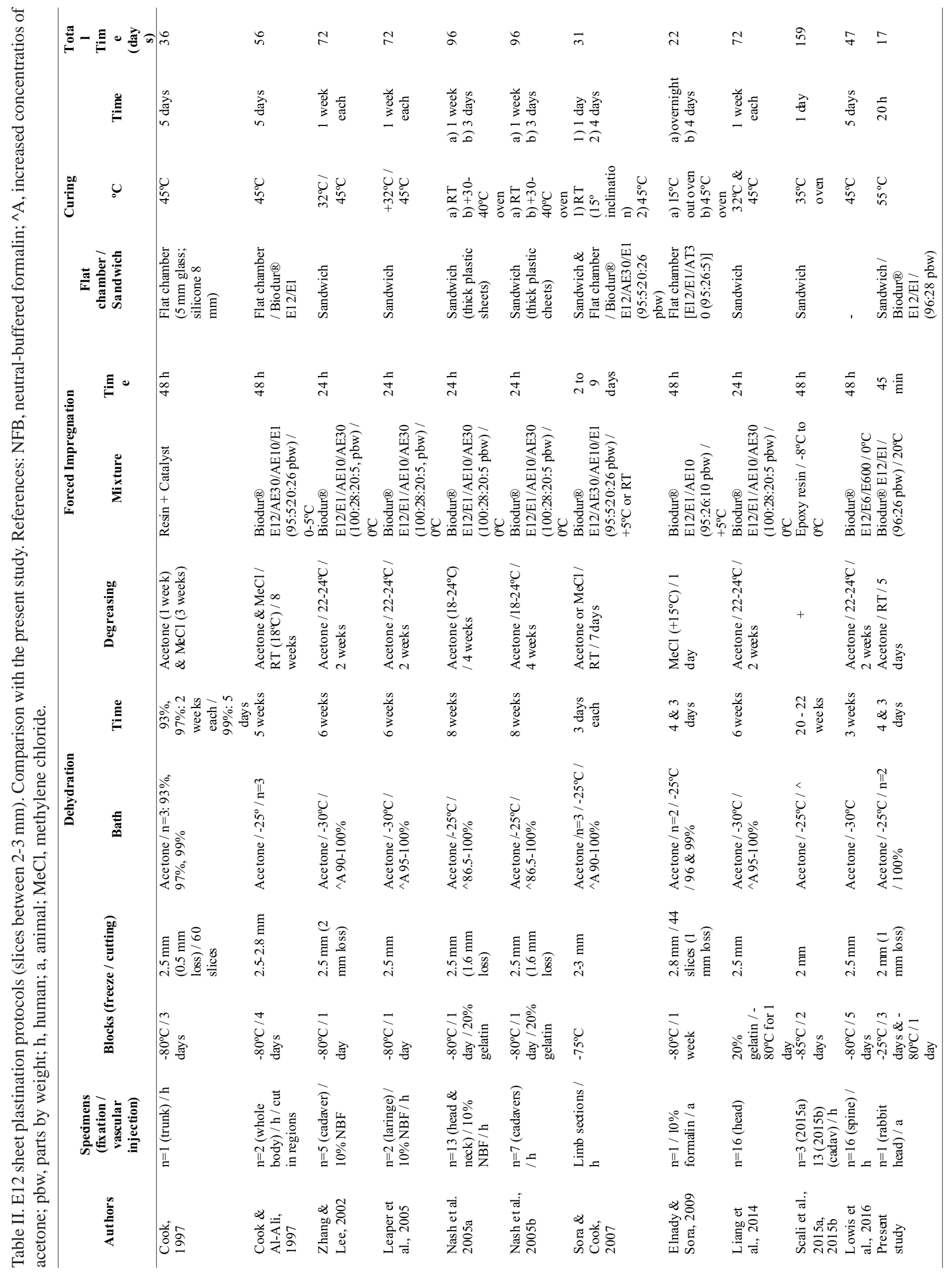


OTTONE, N. E.; VARGAS, C. A.; VEUTHEY, C.; DEL SOL, M. \& FUENTES, F. Plastinación de cortes con resina epoxi en una cabeza de conejo-nuevo protocolo rápido con biodur ${ }^{\circledR} \mathrm{E} 12 / \mathrm{E} 1$. Int. J. Morphol., 36(2):441-446, 2018.

RESUMEN: La plastinación es una técnica anatómica de preservación cadavérica que permite la conservación de piezas anatómicas indefinidamente, en forma seca e inodora. Fue creada en 1978 por Gunther von Hagens, en Heidelberg, Alemania. En particular, la técnica de plastinación de cortes, con resina epoxi, permite la generación de secciones delgadas de diversas regiones anatómicas, asegurando una visualización precisa de estructuras anatómicas de difícil acceso mediante disección o exploración de cadáveres. El objetivo de este trabajo fue presentar un nuevo protocolo de plastinación de cortes con resina Biodur ${ }^{\circledR}$ E12/E1, más rápido en su implementación, aplicada por primera vez, en una cabeza de conejo.

PALABRAS CLAVE: Plastinación de cortes; Biodur ${ }^{\circledR}$ E12/E1; Resina epoxi; Conejo; Cabeza.

\section{REFERENCES}

Adds, P. J. \& Al-Rekabi, A. 3-D reconstruction of the ethmoidal arteries of the medial orbital wall using Biodur ${ }^{\circledR}$ E12. J. Plastination, 26:5-10, 2014.

Bickley, H. C. \& Townsend, F. M. Preserving biological material by plastination. Curator, 27(1):65-73, 1984.

Cook, P. \& Al-Ali, S. Submacroscopic Interpretation of Human Sectional Anatomy using Plastinated E12 Sections. J. Int. Soc. Plastination, 12:1727, 1997.

Cook, P. Sheet plastination as a clinically based teaching aid at the University of Auckland. Acta Anat. (Basel), 158(1):33-6, 1997.

Eckel, H. E.; Sittel, C.; Walger, M.; Sprinzl, G. \& Koebke, J. Plastination: a new approach to morphological research and instruction with excised larynges. Ann. Otol. Rhinol. Laryngol., 102(9):660-5, 1993.

Elnady, F. \& Sora, M. C. Anatomical exploration of a dicephalous goat kid using sheet plastination (E12). Congenit. Anom. (Kyoto), 49(2):66-70, 2009.

Fritsch, H.; Pinggera, G. M.; Lienemann, A.; Mitterberger, M.; Bartsch, G. $\&$ Strasser, H. What are the supportive structures of the female urethra? Neurourol. Urodyn., 25(2):128-34, 2006.

Leaper, M.; Zhang, M. \& Dawes, P. J. An anatomical protrusion exists on the posterior hypopharyngeal wall in some elderly cadavers. Dysphagia, 20(1):8-14, 2005.

Liang, L.; Diao, Y.; Xu, Q. \& Zhang, M. Transcranial segment of the trigeminal nerve: macro-/microscopic anatomical study using sheet plastination. Acta Neurochir. (Wien), 156(3):605-12, 2014.

Nash, L.; Nicholson, H. D. \& Zhang, M. Does the investing layer of the deep cervical fascia exist? Anesthesiology, 103(5):962-8, $2005 \mathrm{~b}$.

Nash, L.; Nicholson, H.; Lee, A. S.; Johnson, G. M. \& Zhang, M. Configuration of the connective tissue in the posterior atlanto-occipital interspace: a sheet plastination and confocal microscopy study. Spine (Phila Pa 1976), 30(12):1359-66, 2005a.

Ottone, N. E. Gunther von Hagens, creator of plastination. Historical review and technical development. Rev. Argent. Anat. Online, 4(2):70-6, 2013.

Ottone, N. E.; Cirigliano, V.; Bianchi, H. F.; Medan, C. D.; Algieri, R. D.; Borges Brum, G. \& Fuentes, R. New contributions to the development of a plastination technique at room temperature with silicone. Anat. Sci. Int., 90(2):126-35, 2015
Ottone, N. E.; Cirigliano, V.; Lewicki, M.; Bianchi, H. F.; Aja-Guardiola, S.; Algieri, R. D.; Cantin, M. \& Fuentes, R. Plastination technique in laboratory rats: An alternative resource for teaching, surgical training and research development. Int. J. Morphol., 32(4):1430-5, 2014.

Ottone, N. E.; del Sol, M. \& Fuentes, R. Report on a sheet plastination technique using commercial epoxy resin. Int. J. Morphol., 34(3):103943, 2016.

Ottone, N. E; Baptista, C. A. C.; Latorre, R.;Bianchi, H. F.; del Sol, M. \& Fuente, R. E12 Sheet plastination: Techniques and application. Clin. Anat., 2017. Doi:10.1002/cca.23008.

Scali, F.; Nash, L. G. \& Pontell, M. E. Defining the morphology and distribution of the alar fascia: a sheet plastination investigation. Ann. Otol. Rhinol. Laryngol., 124(10):814-9, 2015a.

Scali, F.; Pontell, M. E.; Nash, L. G. \& Enix, D. E. Investigation of meningomyovertebral structures within the upper cervical epidural space: a sheet plastination study with clinical implications. Spine J., 15(11):2417-24, $2015 \mathrm{~b}$.

Soal, S.; Pollard, M.; Burland, G.; Lissaman, R.; Wafer, M. \& Stringer, M. D. Rapid ultrathin slice plastination of embalmed specimens with minimal tissue loss. Clin. Anat., 23(5):539-44, 2010.

Sora, M. C. \& Cook, P. Epoxy plastination of biological tissue: E12 technique. J. Int. Soc. Plastination, 22:31-9, 2007.

Sora, M. C. \& Matusz, P. General considerations regarding the thin slice plastination technique. Clin. Anat., 23(5):734-6, 2010.

Sora, M. C.; Brugger, P. C. \& Strobl, B. Shrinkage during E12 plastination. J. Int. Soc. Plastination, 17:23-7, 2002.

Sora, M. C.; Jilavu, R.; Grübl, A.; Genser-Strobl, B.; Staykov, D. \& Seicean, A. The posteromedial neurovascular bundle of the ankle: an anatomic study using plastinated cross sections. Arthroscopy, 24(3):258-63.e1, 2008.

Sora, M. C.; Strobl, B. \& Radu, J. High temperature E12 plastination to procedure ultra-thin sheets. J. Int. Soc. Plastination, 19:22-5, 2004.

Thorpe Lowis, C. G.; Zhang, M. \& Amin, N. F. Fine configuration of thoracic type II meningeal cysts: Macro- and microscopic cadaveric study using epoxy sheet plastination. Spine (Phila Pa 1976), 41(20):E1195-200, 2016

von Hagens, G. Biodur Epoxy Resins for Plastination. In: von Hagens, G. Heidelberg Plastination Folder. Collection of Technical Leaflets of Plastination. Heidelberg, Biodur Products GmbH, 1986.

von Hagens, G. Impregnation of soft biological specimens with thermosetting resins and elastomers. Anat. Rec., 194(2):247-55, 1979.

von Hagens, G.; Tiedemann, K. \& Kriz, W. The current potential of plastination. Anat. Embryol. (Berl.), 175(4):411-21, 1987.

Zhang, M. \& Lee, A. S. The investing layer of the deep cervical fascia does not exist between the sternocleidomastoid and trapezius muscles. Otolaryngol. Head Neck Surg., 127(5):452-4, 2002.

\section{Correspondig author:}

Dr. Nicolás Ottone

Laboratory of Plastination \& Anatomical Techniques

Dental School

Universidad de La Frontera.

Temuco

CHILE

E-mail: nicolas.ottone@ufrontera.cl 